\title{
Pengembangan Industri Kreatif di Panti Asuhan Miftahunnajah Banguntapan Bantul Yogyakarta Berupa Pendampingan Pembuatan Produk Kreatif dari Bahan Limbah Konveksi (Kain Perca)
}

\author{
Yasrin Zabidi \\ Program Studi Teknik Industri \\ Sekolah Tinggi Teknologi Adisutjipto \\ J1. Janti Blok R Lanud Adisutjipto Yogyakarta \\ yazma_2000@yahoo.com
}

\begin{abstract}
Miftahunnajah Orphanage is a community group that organizes pesantren education for orphans. For that purpose, the orphanage management needs a lot of operational expenses in the organization of education and to fulfill the needs of the students santri. So far, the funds used for operations are mostly dependent on donors from donors. The santri in this orphanage have good potential to be developed in order to be more economically independent and not only rely on donor donations or existing funders. While in the neighborhood around the orphanage many resources that can be raised to be developed in the form of creative industries. One of the existing resources is the existence of scrap wastes from small convection industry in Yogyakarta. Creativity and innovation santri-santri Miftahunnajah orphanage needs to be developed in order to capture the opportunities that exist in the vicinity. The solution to solve the problem of lack of creativity and innovation of the santri at Miftahunnajah Orphanage is to provide guidance for business counseling. Therefore in the activities of Community Service T.A. 2017/2018, the proposer conducted advisory activities to nurture and guide the Orphanage Miftahunnajah in making creative products and innovations from waste patchwork materials that exist in the surrounding environment to be a creative product and can be marketed so as to support the orphanage economy and become the Orphanage economically independent. The steps undertaken in the Community Service activities are as follows: 1) Conducting a survey to find out the condition of Orphanage Miftahunnajah in Wonocatur Banguntapan area, 2) Conducting data of creative industries appropriate for guidance/mentoring, 3) Conducting business assistance in the form of guidance of creating creative and innovative products from waste materials that can be developed at Miftahunnajah Wonocatur Banguntapan orphanage. The result of this community service activity is children at Miftahunnajah Orphanage can make creative and innovative product from waste material of patchwork.
\end{abstract}

Keywords : creative industry; production process

\begin{abstract}
Abstrak
Panti Asuhan Miftahunnajah merupakan kelompok masyarakat yang mengelenggarakan pendidikan pesantren untuk anak anak yatim. Untuk tujuan tersebut pengelola panti asuhan tersebut membutuhkan biaya operasional yang tidak sedikit dalam penyelenggaraan pendidikan dan memenuhi kebutuhan hidup santri-santrinya. Selama ini dana yang digunakan untuk operasional sebagian besar masih menggantungkan pada donatur dari para penyandang dana. Santri-santri yang ada di Panti Asuhan ini mempunyai potensi yang cukup bagus untuk dikembangkan agar bisa lebih mandiri secara ekonomi dan tidak hanya menggantungkan pada sumbangan donator atau penyandang dana yang ada. Sementara di lingkungan sekitar panti asuhan
\end{abstract}


tersebut banyak sumber daya yang bisa diangkat untuk dikembangkan dalam bentuk industri kreatif. Salah satu sumber daya yang ada adalah adanya limbah kain perca hasil dari industri kecil konveksi yang ada di Yogyakarta. Kreatifitas dan inovasi santri-santri panti asuhan Miftahunnajah ini perlu dikembangkan agar bisa menangkap peluang yang ada di sekitarnya. Solusi untuk mengatasi permasalahan kurangnya kreatifitas dan inovasi para santri di Panti Asuhan Miftahunnajah adalah dengan memberikan pendampingan bimbingan usaha. Oleh karena itu dalam kegiatan Pengabdian pada Masyarakat T.A. 2017/2018 ini, pengusul melakukan kegiatan pendampingan untuk membina dan membimbing Panti Asuhan Miftahunnajah dalam membuat produk kreatif dan inovasi dari bahan limbah kain perca yang ada di lingkungan sekitarnya untuk menjadi produk kreatif dan bisa dipasarkan sehingga dapat mendukung perekenomian panti asuhan dan menjadi Panti Asuhan yang mandiri secara ekonomi. Langkah-langkah yang dilakukan dalam kegiatan Pengabdian pada Masyarakat ini adalah sebagai berikut :1) Melakukan survey untuk mengetahui kondisi Panti Asuhan Miftahunnajah di wilayah Wonocatur Banguntapan, 2) Melakukan pendataan industri kreatif yang layak untuk dilakukan pembinaan/pendampingan, 3) Melakukan pendampingan usaha berupa bimbingan pembuatan produk kreatif dan inovatif dari bahan limbah yang bisa dikembangkan di Panti asuhan Miftahunnajah Wonocatur Banguntapan. Hasil dari kegiatan pengabdian kepada masyarakat ini adalah anak-anak di Panti Asuhan Miftahunnajah dapat membuat produk kreatifitas dan inovasi dari bahan limbah kain perca.

Kata Kunci : industri kreatif; proses produksi

\section{Latar Belakang Masalah}

Dalam era digital, peluang industri kreatif semakin menemukan titik cerah. Besarnya perhatian masyarakat akan sesuatu yang berbeda, unik dan menarik, tentunya menjadi segmentasi tersendiri. Konsep industri kreatif sendiri merupakan sebuah usaha baru yang mengintensifkan informasi dan kreativitas dengan mengandalkan ide dan pengetahuan dari Sumber Daya Manusia sebagai faktor utama penggerak utama perekonomiannya. Usaha ini menekankan pada kreativitas, ide, inovasi, dari Sumber Daya Manusia dalam menyajikan produk dan dapat membuka pasar persaingan produk yang inovatif dan dapat bersaing di pasar. Industri kreatif yang berkembang saat ini memiliki banyak jenis. Tak hanya berfokus pada kerajinan tangan, namun lebih luas merambah mulai dari arsitektur, periklanan, seni, desain, fashion, film, musik, fotografi, gadget, software, games, dan lainnya yang menyangkut kreativitas. Hal ini menandakan bahwa industri ini tak terfokus pada satu jenis usaha saja, namun memiliki peluang yang cukup besar dengan jenis usaha yang luas.

Ekonomi kreatif adalah gagasan baru sistem ekonomi yang menempatkan informasi dan kreativitas manusia sebagai faktor produksi yang paling utama. Ide merupakan barang mahal dalam ekonomi kreatif, karena ide-ide yang kreatif inilah yang akan mendorong terciptanya inovasi-inovasi yang kemudian menjadi solusi baru dan produk baru, dimana ini merupakan jawaban selama ini atas masalah minimnya kualitas produk yang sesuai dengan kebutuhan pasar. Ekonomi kreatif akan menggeser produk-produk hasil industri konvensional dan memberikan solusi baru yang lebih tepat untuk kebutuhan pasar. Untuk itu perlu ditumbuhkan industry kreatif yang ada di masyarakat sehingga bisa meningkatkan kesejahteraan masyarakat. Dengan tumbuhnya kreatifitas masyarakat ini akan bisa menggerakkan perekonomian masyarakat. Dengan demikian akan tercipta suatu masyarakat yang mandiri,

Panti asuhan Miftahunnajah yang terletak di Jl. Wonocatur Bantul Yogyakarta dalah salah satu dari sekelompok masyarakat yang berpotensi untuk ditumbuhkan kreatifitas dan inovasinya agar menjadi masyarakat yang mandiri. Sebagian besar Panti asuhan selama ini 
lebih memfokuskan kegiatan keagamaan mempunyai peluang untuk ditumbuhkan kraetifitasnya. Potensi yang ada dimiliki oleh Panti asuhan Miftahunnajah yang secara geografis terletak di daerah perkotaan mempunyai peluang yang cukup besar dalam mengembangkan industri kreatif. Panti Asuhan Miftahunnajah merupakan kelompok masyarakat yang mengelenggarakan pendidikan pesantren untuk anak anak yatim. Untuk tujuan tersebut pengelola panti asuhan tersebut membutuhkan biaya operasional yang tidak sedikit dalam penyelenggaraan pendidikan dan memenuhi kebutuhan hidup santri-santrinya. Selama ini dana yang digunakan untuk operasional sebagian besar masih menggantungkan pada donatur dari para penyandang dana. Santri-santri yang ada di Panti Asuhan ini mempunyai potensi yang cukup bagus untuk dikembangkan agar bisa lebih mandiri secara ekonomi dan tidak hanya menggantungkan pada sumbangan donator atau penyandang dana yang ada. Sementara di lingkungan sekitar panti asuhan tersebut banyak sumber daya yang bisa diangkat untuk dikembangkan dalam bentuk industri kreatif. Salah satu sumber daya yang ada adalah adanya limbah kain perca hasil dari industri kecil konveksi yang ada di Yogyakarta. Kreatifitas dan inovasi santri-santri panti asuhan Miftahunnajah ini perlu dikembangkan agar bisa menangkap peluang yang ada di sekitarnya. Solusi untuk mengatasi permasalahan kurangnya kreatifitas dan inovasi para santri di Panti Asuhan Miftahunnajah adalah dengan memberikan pendampingan bimbingan mengolah bahan limbah kain perca menjadi produk kereatif dan inovatif serta dapat dipasarkan sehingga dapat mendukung perekenomian panti asuhan dan menjadi Panti Asuhan yang mandiri secara ekonomi

\section{Metodologi Pelaksanaan}

Target luaran program Pengabdian pada Masyarakat ini agar Panti Asuhan Miftahunnajah ini dapat menghasilkan produk assesoris (bros, bando, ikat rambut) dari bahan limbah hasil konveksi (kain perca). Selain itu luaran dari kegiatan Pengabdian pada Masyarakat ini akan menjadi salah satu topik materi pekuliahan perencanaan Pengendalian produksi, Proses Manufaktur.

Langkah-langkah yang dilakukan dalam kegiatan Pengabdian pada Masyarakat ini adalah sebagai berikut :

a. Melakukan survey untuk mengetahui kondisi Panti Asuhan Miftahunnajah di wilayah Wonocatur Banguntapan.

b. Melakukan pendataan industri kreatif yang layak untuk dilakukan pembinaan/pendampingan

c. Melakukan pendampingan usaha berupa bimbingan pembuatan produk kreatif dan inovatif dari bahan limbah yang bisa dikembangkan di Panti asuhan Miftahunnajah Wonocatur Banguntapan.

\section{Hasil dan Pembahasan}

Kegiatan pelaksanaan Pengabdian Pada Masyarakat untuk Tahun Akademik 2017/2018 ini diwujudkan dalam bentuk pendampingan usaha berupa bimbingan pembuatan produk kreatif dan inovatif dari bahan limbah yang bisa dikembangkan di Panti asuhan Miftahunnajah Wonocatur Banguntapan, sehingga dengan kegiatan ini anak-anak di Panti asuhan Miftahunnajah Wonocatur Banguntapan dapat membuat produk assesoris (bros, bando, ikat rambut) dari bahan limbah hasil konveksi (kain perca). 


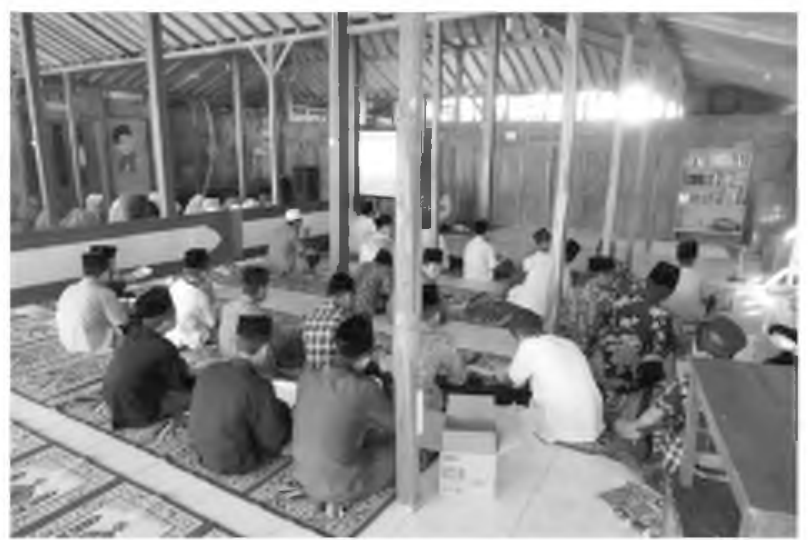

Gambar 1. Peserta Bimbingan Pembuatan Produk dari Kain Perca

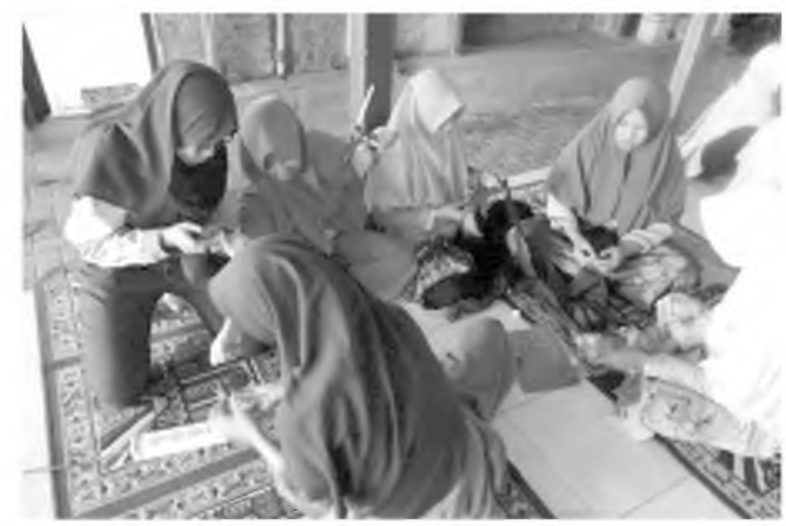

Gambar 2. Peserta sedang praktek pembuatan produk dari kain perca

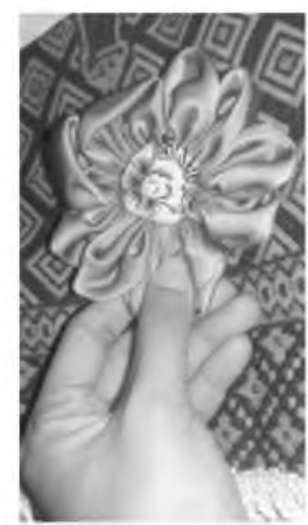

Gambar 3. Contoh produk dari kain perca

\section{Kesimpulan}

Berdasarkan pada pelaksanaan program Pengabdian Pada Masyarakat T.A. 2017/2018, peserta pendampingan usaha bimbingan pembuatan produk aksesoris dari kain perca sangat antusias mengikuti kegiatan in dan mereka sudah dapat membuat produk dari kain perca seperti bros, bando, ikat rambut. 


\section{Daftar Pustaka}

[1] Kotler, 2009, Manajemen Pemasaran,Edisi 13, Erlangga

[2] Zimmerer, Scarborough, 2008, Kewirausahaan: Manajemen Usaha Kecil, Salemba Empat, Jakarta

[3] Wayne C. Turner,Janti Gunawan, 2000, Pengantar Teknik \& Sistem Industri, Jilid 1, Guna Widya

[4] Rohit Ramaswamy, 1996, Design and Management of Service Process, AddisonWesley Publishing Company, In 
